\title{
MEMOIRS
}

\section{ROBERT THODEY}

OUR departed colleague and friend was born at Hornsey in North London on Ist August, 1875 , and his life was brought to a close on $13^{\text {th }}$ August, 1935, leaving us to mourn the loss of a faithful and true-hearted man and to rejoice in the shining example which he ever set of probity and industry. He was educated at Enfield Grammar School, England, and was evidently a scholar of great promise and on terms of deep affection with the Principal who, nearly twenty years after their parting, displayed to the writer with considerable pride a remarkable collection of photographs taken by his former pupil and regularly despatched to him from the Antipodes. At the age of sixteen Robert, an only child, accompanied his parents to Australia. Mr Thodey, senior, being in delicate health, decided to try the climate of Melbourne, to which place he was naturally attracted by the presence of his brother who was the Editor of the Australasian Banking and Insurance Record and left his mark on that great and infuential journal.

Our subject entered the service of the Australian Mutual Provident Society in Melbourne at the age of sixteen as an Articled Clerk and was transferred to the Head Office Staff in Sydney in February, 1898 , as a promising actuarial student. He passed a number of office examinations and in I90r completed the incredibly difficult feat of passing all the examinations to qualify him as Fellow of the Institute of Actuaries (London) so far from the facilities offered to London students. He was appointed Manager of the Industrial Department of the Society in I91I. In 1927 he became the Society's Manager for the United Kingdom which post he resigned after three years' service and returned to Australia to practise his profession as Consulting Actuary. In November $193^{\circ}$ he became associated with the Provident Life Assurance Company in an advisory capacity and in 1933 was appointed Attorney for that Company in Australia.

It would be difficult to write of the late Robert Thodey without using superlatives. He was evidently a model student. His hunger for knowledge of a useful nature was insatiable. His skill in photography and other crafts was far above the ordinary. He was a model son and devoted himself to the comfort and companionship of an ailing parent. He married in 1922 Miss K. Gates and leaves his widow to mourn his loss. From his entry into business life he was a model clerk, and for zeal, accuracy, industry and thoroughness was accepted and regarded as the highest standard and example. His reverence for authority was almost absolute and made for orthodoxy rather than originality. In character he 
was rigidly true and scrupulously honest in every sense of the word and intolerant of compromise. A strict disciplinarian, he was yet kind and thoughtful for others. His somewhat monastic upbringing and absence of sporting contacts and companionship in youth tended to make him somewhat shy and extremely sensitive to criticism. However, he conducted himself in the high and important offices to which he attained with conspicuous ability and success. Outside his official duties he took his part as a member of the Insurance Institute of New South Wales and of the Actuarial Society of Australasia, holding the office of President in each body and writing several valuable papers. Robert Thodey was one of those rare people of whom it may be said that:

"Of all his tale of days, not one

Has passed and left its unlaid ghost

To seek a light for ever lost

Or wail a deed for ever done."

A. C. H.

\section{ALFRED LOEWY}

Professor Alfred Loewy, who died on 25th January last, was another instance of a mathematician who took up actuarial science. Born on 2oth June, 1873, at Rawitsch in Posen, he became Professor in I 902 at Freiburg. A voluminous and versatile writer on actuarial topics, he will be best remembered in this country for valuable contributions regarding the employment of Stieltje's integral, and for suggestions on the development of actuarial notation, although much of his other work is also of great merit (see $\mathcal{F} . I . A$. Vol. LXIv, p. $5^{8}$ ). His productive capacity of late years is the more remarkable in view of the fact that he suffered severely from eye trouble. Much regret will be felt at the termination of a career that had by no means run its course.

G. W. R. 